\title{
JOURNAL
}

of Health Inequalities

\section{Nutrition and public health}

\author{
Witold A. Zatoński',2, Kinga Janik-Koncewicz ${ }^{1,2}$ \\ 'Maria Skłodowska-Curie Memorial Cancer Center and Institute of Oncology, Warsaw, Poland \\ ${ }^{2}$ Health Promotion Foundation, Nadarzyn, Poland
}

KEY WORDS: nutrition, public health, physical activity, body weight.

ADDRESS FOR CORRESPONDENCE: Witold A. Zatoński, Professor of Medicine, Health Promotion Foundation, 51 Mszczonowska St., 05-830 Nadarzyn, Poland, phone: +48 2273976 40, e-mail: wazatonski@promocjazdrowia.pl

\section{NUTRITION AND PUBLIC HEALTH}

Proper nutrition, together with healthy body weight and physical activity, are among the key challenges of public health policy. This is especially the case in countries such as Poland, where dietary patterns have not been following optimal trends for the building and maintaining of good population health. Contrary to tobacco smoking and alcohol binge drinking, proper diet and daily physical activity resulting in healthy body mass, are positive factors essential for prevention of non-communicable diseases, and for the success of the strategy of "healthy ageing" which has been implemented by many countries. It is necessary to monitor these factors, analyse and understand their potential contribution to changes in health indicators in Poland and other countries.

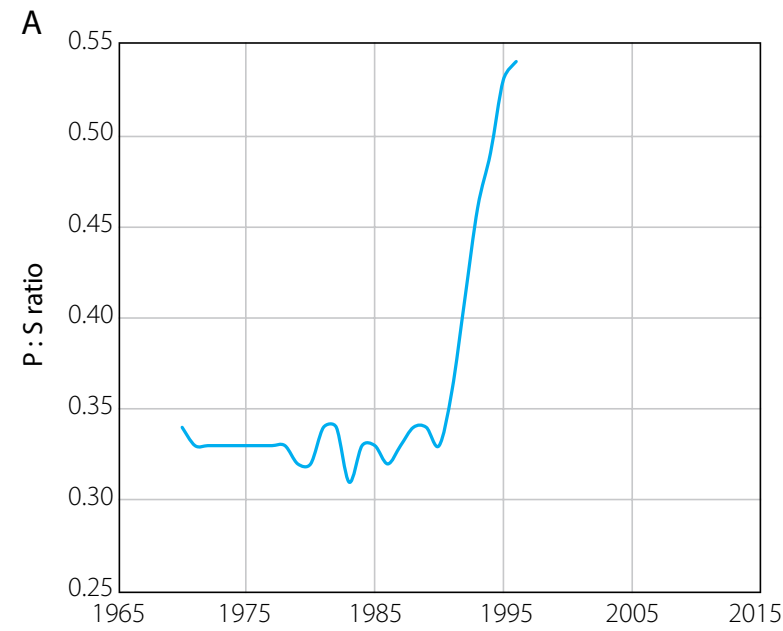

Diet, nutrition and related factors will be among the key topics covered in the Journal of Health Inequalities. In this issue we would like to present the first article describing changes in dietary patterns in Poland in last 30 years. These changes were an effect of the social and economic transformation which occurred in Poland at the end of 1980s and in 1990s.

Current epidemiological knowledge indicates that change in structure of fat consumption was one of the most important reasons behind the cardiovascular transformation that took place in Poland in this period. Figure 1 summarises the phenomenon that had been presented for the first time in British Medical Journal in 1998 [1]. A number of other publications also attempted to explain the cardiovascular transformation in Poland [1-4]. In future issues the Journal of Health Inequalities

B

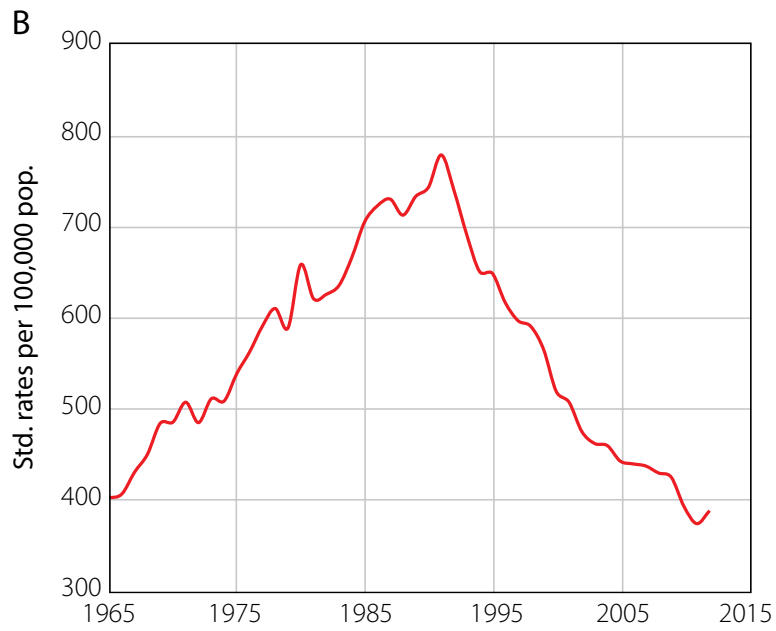

FIG. 1. Polyunsaturated vs. saturated fatty acids (P : S) ratio [5] (A) and cardiovascular disease (CVD) mortality in men aged 45-64 (B) in Poland 
will be returning to issues of nutrition, physical activity and body weight.

\section{DISCLOSURE}

Authors report no conflict of interest.

\section{References}

1. Zatonski WA, McMichael AJ, Powles JW. Ecological study of reasons for sharp decline in mortality from ischaemic heart disease in Poland since 1991. BMJ 1998; 316: 1047-1051.

2. Zatonski WA, Willett W. Changes in dietary fat and declining coronary heart disease in Poland: population based study. BM] 2005; 331: 187-188.

3. Zatonski W, Campos H, Willett W. Rapid declines in coronary heart disease mortality in Eastern Europe are associated with increased consumption of oils rich in alpha-linolenic acid. Eur J Epidemiol 2008; 23: 3-10.

4. Zatońska K, Campos H, Ilow R, Janik-Koncewicz K, Różańska D, Regulska-Ilow B, Połtyn-Zaradna K, Szuba A, Zatoński WA. Dietary intake and adipose tissue level of specific fatty acids in a selected group from the Lower Silesia population. Ann Agric Environ Med 2012; 19: 389-394.

5. Niedziałek Z, Figurska K, Morawska M, Boruc T. Spożycie żywności w Polsce w latach 1950-1996 w przeliczeniu na energię i składniki odżywcze [Food consumption in Poland converted into energy and nutrients, 1950-1996]. National Food and Nutrition Institute, Warsaw 1997. 